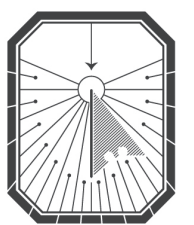

KYIV-MOHYLA

LAW \& POLITICS JOURNAL

KYIV-MOHYLA SCHOLARLY PEER-REVIEWED JOURNALS

Problems of Adherence by Ukraine to International Commitments in Resolution of Cases in Trials that Took Place in Temporarily Occupied Territories

Author(s): Iryna Basysta, Volodymyr Galagan

Source: Kyiv-Mohyla Law and Politics Journal 4 (2018): 119-135

Published by: National University of Kyiv-Mohyla Academy

http://kmlpj.ukma.edu.ua/ 


\title{
Problems of Adherence by Ukraine to International Commitments in Resolution of Cases in Trials that Took Place in Temporarily Occupied Territories ${ }^{1}$
}

\author{
Iryna Basysta \\ Lviv State University of Internal Affairs, \\ Department of Criminal Procedure
}

\author{
Volodymyr Galagan \\ National University of Kyiv-Mohyla Academy, \\ Department of Criminal Law and Criminal Procedure
}

\begin{abstract}
The legal procedure employed in criminal law where an individual was convicted by the courts of a temporarily occupied area of Ukraine has faced a number of challenges. When the European Court of Human Rights (ECHR) finds that Ukraine has run afoul of its international commitments during a trial, the records of such criminal proceedings shall be considered by the Supreme Court's Grand Chamber, which shall apply the legal procedure regulations for newly discovered or exceptional circumstances, as outlined in Article 34 of the 2012 Criminal Procedure Code of Ukraine. At the same time, such hearing would be hindered by absence of reliable procedural regulations for retention of records in a criminal case in the occupied territory, and therefore are likely not available for review by the Supreme Court. In this article, the authors attempt to present both the objective challenges and the possible methods and means to address them to the international scholarly community. These challenges stand in the way of the reform of the Ukrainian judicial system as a whole, and particularly affect Ukraine's adherence to its international commitments as it resolves of cases tried in the temporarily occupied territories. Considering the above, the authors analyzed the legislation and draft laws of Ukraine, as well as a number of international legislative documents, and outlined their own evidence-supported academic opinion on how to resolve the problem as well as articulated their approach to the organizational and legislative aspects of Ukraine's adherence to its international commitments as the country's courts resolve such criminal cases.
\end{abstract}

$1 \quad$ For conception of the research idea and for motivation to act, the authors express their sincere gratitude to Doctor of Legal Sciences, Professor, Judge of the Supreme Court's Grand Chamber, Leonid Loboiko (Kyiv, Ukraine), and for providing opportunities to communicate with international law scholars' community - to Doctor of Legal Sciences, Tetiana Rudak, VicePrincipal for International Relations of the King Danylo University (Ivano-Frankivsk, Ukraine). Additionally the authors wish to thank Mariya Dmytriyeva for assistance in translation and Kerry Ann Stare for her valuable assistance in article editing. 
Key Words: criminal procedure, Supreme Court, European Court of Human Rights (ECHR), international commitments, retrieval of records, restoration of criminal procedure records.

\section{Introduction}

Part 1, Article 17 of the Law of Ukraine "On Enforcement of Judgments and the Application of the Case-Law of the European Court of Human Rights" of February 23, 2006, No. 3477-IV, the courts of all instance are to apply the $195^{\circ}$ Convention for the Protection of Human Rights and Fundamental Freedoms. This application includes all Protocols to the Convention as well as ECHR case law as a source of law. For over two decades, Ukrainian legislators have been trying to improve the statutory mechanism for enforcing ECHR judgments and have achieved some positive results. The ongoing judicial reform in Ukraine is by its nature innovative. New courts have been established: in particular, the highest national judicial instance - the Supreme Court, which became operational on December 15, 2017. According to Part 3, Article 463 of the Criminal Procedure Code of Ukraine, a request for review of judgment due to exceptional circumstances, shall be filed for consideration before the Supreme Court's highest body - the Grand Chamber, in cases where an international judicial body, whose jurisdiction Ukraine recognizes, rules that Ukraine violated its international commitments while the case was being tried. The law outlines the legal procedure for addressing such a request and for considering it. The Supreme Court will then conduct the proceeding according to its specific powers, and form its own legal positions, thus securing Ukraine's compliance with its international commitments. Yet, it must be stated that there area number of existing gaps and controversies that substantially hinder the positive trends.

ECHR has stated on numerous occasions that Ukraine violated its international commitments during pre-trial investigations and judicial examination; in particular, several articles of the $195^{\circ}$ Convention for the Protection of Human Rights and Fundamental Freedoms (the Convention). Analysis of the violations shows that they fall under Article 2 "Right to Life," Article 3 "Prohibition of Torture," Article 5 "Right to Liberty and Security," Article 6 "Right to a Fair Trial," Article 8 "Right to Respect for Private and Family Life," Article 10 "Freedom of Expression," Article 11 "Freedom of Assembly and Association," Article 13 "Right to an Effective Remedy," as well as other Articles of this Convention.

In particular, ECHR's rulings concerning Ukraine refer to various violations of rights and freedoms, and established prohibitions, as defined in the Convention and Protocols thereto. The rulings during the four-year period can be categorized by the Article violated: Article 2 "Right to Life" (Basyuk v. Ukraine, no. 51151/10, decision of November 5, 2015, became final on February 5, 2016); Article 3 "Prohibition of Torture" (Pomilyaykov. Ukraine, no. 6o426/11, decision of February 11, 2016, became final on May 11, 
2016); Article 5 "Right to Liberty and Security" (Kushchv. Ukraine, no. 53865/11), decision of December 3, 2015, became final on March 3, 2016); Article 6 "Right to a Fair Trial" (Chumakv. Ukraine, no. 6o79o/12, decision of May 19, 2016 - a right to implementation of court decision within a reasonable term), (Pavlov and others $v$. Ukraine, no. 8237/o6 and 13 other applications - see Table in Appendix to the judgment), ${ }^{2}$ decision of November 5, 2015 - a right to pre-trial investigation and judicial examination within a reasonable term), (Yaremenko v. Ukraine (No. 2), no. 66338/o9, decision of April 30, 2015, became final on July 30, 2015 - a right to a fair trial); Article 8 "Right to Respect for Private and Family Life" (Rodzevillo v. Ukraine, no. 38771/05, decision of January 14, 2016, became final on April 14, 2017); Article 10 "Freedom of Expression" (Shrydka v. Ukraine, no. 17888/12, decision of October 30, 2014, became final on January 30, 2015); Article 11 "Freedom of Assembly and Association" (Veniamin Tymoshenko and others v. Ukraine, no. 48408/12, decision of October 2, 2014, amended on November 13, 2014, based on Rule 81 of the Court Rules and Regulations, became final on January 2, 2015), Article 13 "Right to an Effective Remedy" (Savinov v. Ukraine, no. 5212/13, decision of October 22, 2015, became final on January 22, 2016), Article 34 "Individual Applications" (Sergey Antonov v. Ukraine, no. 40512/13, decision of October 22, 2015, became final on January 22, 2016), ${ }^{3}$ and others.

The First Deputy Minister of Justice of Ukraine, Natalia Bernatska, stated that

of 2018, the government of Ukraine does not have outstanding commitments in implementing ECHR rulings. In particular, the last year budget of UAH 65 o million, earmarked for implementation of ECHR rulings, was used only partly. Unlike now, in 2014 the situation with implementation of ECHR rulings was catastrophic: out of 47 countries, Ukraine had the highest number of applications to the European Court. Of them, the largest number was about failure to implement the decisions of national courts. Today, Ukraine is no longer the country with the highest number of such applications. ${ }^{4}$

As the First Deputy Minister pointed out, at that time, the debt owed based on ECHR rulings was approximately Euro 35 million, while the budget earmarked for these

2 Pavlov and Others v. Ukraine (ECHR November 5, 2015), accessed September 14, 2018, https://hudoc.echr.coe.int/ eng\#\{\%22appno\%22:[\%228237/06\%22],\%22itemid\%22:[\%22001-158535\%22]\}.

ECHR decisions made regarding Ukraine. Ministry of Justice of Ukraine (old version), accessed September 10, 2018, http://old.minjust.gov.ua/9329.

Natalia Bernatska, "Miniust znayshov mehanizm vykonannia rishennia ESPL u spravi "Burmych ta inshi proty Ukrainy [Ministry of Justice Found a Mechanism to Implement ECHR Judgment in Case Burmych and others v. Ukraine]," accessed September 10, 2018, https://minjust.gov.ua/ news/ministry/nataliya-bernatska-minyust-znayshov-mehanizm-vikonannya-rishennya-espl-uspravi-burmich-ta-inshi-proti-ukraini. 
obligations was only UAH 74 million. To reduce the debt, the practice of amicable settlement was introduced. In essence, it was an agreement that the ECHR would not assign indemnification at all, or assign a minimal one. Instead, Ukraine agreed to implement the decisions of national courts. Thanks to this approach, last year some funds earmarked for payment of indemnifications judged by the ECHR remained. ${ }^{5}$

To properly implement ECHR rulings, Ukraine assigned responsible agencies and formulated a procedure, subject to amendment in the law. As the Supreme Court started hearing cases, some problems and challenges emerged, which, to our opinion, could be classified as either organizational or legislative.

\section{One of the organizational challenges is that there are obstacles for implementation of procedural requirements within Ukrainian borders. The international community is aware that since 2014, some areas in the East of the Ukrainian territory have been occupied by unlawful militants and are not controlled by Ukraine.}

In addition to having other large-scale negative impacts, this also creates certain complications for Ukraine's adherence to its international commitments for resolving court cases.

In particular, when the ECHR establishes that Ukraine has violated one of its international commitments in a case, the Supreme Court's Grand Chamber has to consider the records of the criminal proceeding (criminal case) based on the procedural rules for newly discovered or exceptional circumstances as outlined in Chapter 34 of the 2012 Criminal Procedure Code of Ukraine.

According to clause 2 of part 3 of Article 459 of the 2012 Criminal Procedure Code of Ukraine, ${ }^{6}$ exceptional circumstances include cases, when an international judicial body, whose jurisdiction Ukraine recognizes, establishes that Ukraine violated of its international commitments during the resolution of a court case. The only judicial body mandated to consider applications of convicted persons for review due to the ECHR citing a violation of international commitments during the trial (clause 2 of Part 1, Article 400-12 of the old Criminal Procedure Code of Ukraine 196o (repealed), clause 2 of Part 3, Article 459 of the current 2012 Criminal Procedure Code of Ukraine), is the Supreme Court's Grand Chamber.

Implementing the mentioned mandate to review the applications of convicted persons is especially challenging for the Supreme Court's Grand Chamber when examining criminal cases from courts in two Eastern oblasts of Ukraine: Donetska and Luhanska. The Grand Chamber is often unable to retrieve criminal cases records

5 Bernatska, "Ministry of Justice Found a Mechanism to Implement ECHR Judgment in Case Burmych and others v. Ukraine."

6 Kryminalny protsesualnyi kodeks Ukrainy [Criminal Procedure Code of Ukraine] of April 13, 2012, accessed June 20, 2018, http://zakon.rada.gov.ua/laws/show/4651-17/page16. 
from these courts, as they are located in occupied territories. Absence of these records or some part thereof creates a problem with uniform application of certain norms of Ukrainian criminal procedural law which governs the Supreme Court's Grand Chamber mandate to review court decisions.

\section{Conclusion 1}

The current 2012 Criminal Procedure Code of Ukraine is silent as to the retrieval of criminal case records by the Supreme Court. Therefore, it is difficult to apply the norms of the current criminal procedural legislation on this issue because the current 2012 Criminal Procedure Code of Ukraine does not provide for the direct obligation for the Supreme Court to request the records of a criminal case, in which ECHR identified a violation during the course of pretrial investigation or legal proceedings. This does not mean that the proceeding in the Supreme Court has to be conducted without such records; the Supreme Court judges are required to review the facts of the case established by the trial level and appeal courts. ${ }^{7}$ In some cases, the Supreme Court can examine these circumstances in full based on the available ECHR decision, which refers to previous procedural decisions of the Ukrainian courts, and the available records of the criminal case which are at the Supreme Court's disposal. Otherwise, when the available materials are not sufficient for the Supreme Court to come to a decision and/ or the decisions of the courts of lower instances are nullified (in full or in part), there should be an effective mechanism for obtaining the criminal case records that cannot be retrieved from the territories currently not under Ukrainian control.

It would be logical that the criminal procedural legislation should clearly define the exceptional circumstances under which the special procedure of restoration of a criminal case record may be applied. This procedure differs from the already existent general procedure, in particular, in subjects, time limitations, grounds, procedural order, among other elements. The authors of this article believe that failure by the courts in the temporarily occupied territories of Ukraine to provide criminal case records in response to a Supreme Court's request constitutes an exceptional circumstance. This provision should be applicable under a certain condition - that the materials that came from ECHR after a consideration of a criminal case are not adequate for the Supreme Court to make its own decision regarding overturning the decisions of lower courts.

At the same time, absence of criminal case records at the Supreme Court cannot be regarded as a basis for refusal to consider applications of the convicted persons in cases where the ECHR has identified violations of the Convention.

7 Anna Vronska, "Shcho neobkhidno znaty pro vnutrishniu orhanizatsiu, format rishen ta systematyzatsiiu sudovoi praktykyVerkhovnoho Sudu? [What You Should Know About Internal Structure, Format of Decisions and Systematization of Case Law of the Supreme Court?]," accessed September 10, 2018, http://jurliga.ligazakon.ua/news/2018/2/23/168669. htm. 


\section{A certain legislative ambiguity is a considerable factor complicating resolution of this legal problem.}

In particular, the latest amendments to the Criminal Procedure Code of Ukraine now require the Supreme Court judges to consider applications of convicted persons for review in cases where the ECHR established violations of the Convention (and, correspondingly, violation by Ukraine of its international commitments in the judicial consideration of the case) following the procedure for review of court decisions under exceptional circumstances.

This provision is articulated in clause 15 of Section XI "Transitional provisions" of the Criminal Procedure Code of Ukraine:

...Appellate and cassation appeals, applications for review of court decisions in criminal cases that were considered before this Code came into effect, or in the cases, whose consideration was not finished when this Code came into effect, shall be filed and considered based on the procedure that was in effect before this Code came into effect, taking into account provisions stipulated in $\S 3$, Section 4 of the Law of Ukraine "On Amendments to Economic Procedure Code of Ukraine, Civil Procedure Code of Ukraine, Administrative Procedure Code of Ukraine, and other legislative acts" of October 3, 2017, No. 2147-VIII. ${ }^{8}$

As currently defined in clause 3 , $\S 3$, Section 4 of the mentioned Law of Ukraine,

...applications for review of court decisions by the Supreme Court of Ukraine in cases, where an international court institution, whose jurisdiction Ukraine recognizes, establishes a violation by Ukraine of its international commitments, when the relevant case was resolved by the court, and where such cases were filed but their consideration was not completed before this Law came into effect, shall be transferred to the Supreme Court for their consideration based on the rules of review of court decisions due to extraordinary circumstances that are in effect after this Law becomes effective. ${ }^{9}$

8 Zakon Ukrainy "Pro vnesennia zmin do Hospodarkoho protsesualnoho kodeksu Ukrainy, Tsyvilnoho protsesualnoho kodeksu Ukrainy, Kodeksu administratyvnoho sudochynstva Ukrainy ta inshykh zakonodavchykh aktiv [On Amendments to Economic Procedure Code of Ukraine, Civil Procedure Code of Ukraine, Administrative Procedure Code of Ukraine, and Other Legislative Acts]," of October 3, 2017, No. 2147-VIII, accessed June 10, 2018, http:// zakon. rada.gov.ua/laws/show/2147-19.

9 "On Amendments to Economic Procedure Code of Ukraine, Civil Procedure Code of Ukraine, Administrative Procedure Code of Ukraine, and Other Legislative Acts." 
Therefore, this Law, which came into effect on December 15, 2017, did not provide for a transitional period. For this reason, all mentioned applications of the convicted persons were to be transferred to the newly established Supreme Cour ${ }^{10}{ }^{10}$ for consideration based on the rules of review due to extraordinary circumstances, which have been in effect since this Law became effective. The 2012 Criminal Procedure Code of Ukraine in Chapter 34 establishes the procedure of such consideration, but in a rather limited form. Obviously, the Supreme Court's Grand Chamber faces an urgent need to outline their own legal position when reviewing applications from convicted persons. Currently, there is a complete absence of Supreme Court case law on this subject.

Until recently, according to Articles 32,38 of the Law of Ukraine "On the Judiciary and Status of Judges" of July 7, 2010 (which is currently not in effect, except for some provisions) and to the norms of the 1960 Criminal Procedure Code of Ukraine, the mandate to review cases, where an international judicial body (recognized by Ukraine) establishes that the Ukrainian court violated one of its international commitments during court proceedings, was vested in the Supreme Court of Ukraine, which is now under the procedure of dissolution. ${ }^{11}$

Article 32 of this Law had provided that the cases of this category were considered by the Supreme Specialized Court of Ukraine for Civil and Criminal Cases (ceased operating since), according to the rules established for review of cases under the cassation procedure. ${ }^{12}$ In particular, according to Article $400-11$ of the 196 o Criminal Procedure Code of Ukraine (as amended according to Law No. $5^{290}$-VI of September 18 , 2012), the Supreme Court of Ukraine would review criminal court decisions only for reasons pertaining to the procedure established by this Code..$^{13}$

Clause 2 of Part 1, Article 400-12 of the 196o Criminal Procedure Code of Ukraine, lists the reasons for review of court decisions by the Supreme Court of Ukraine that properly came into effect and one of them is when a recognized international judicial body, establishes that Ukraine has violated one of its international commitments during court proceedings. Part 2 of the said Article prohibits the review of court decisions on the grounds required by Clause 2, Part 1 of this Article, with the goal of charging a more serious crime, increasing the scope of charges, or applying it to a sentence of acquittal, judgment or decision to close the case. ${ }^{14}$

10 Translator's note. The Supreme Court of Ukraine is no longer operating and is currently undergoing the process of liquidation as mentioned by the authors. It was replaced as the highest judiciary body of the country by the Supreme Court. They are referred in the text as the Supreme Court of Ukraine and the Supreme Court, respectively.

Zakon Ukrainy "Pro sudoustriy i status suddiv [On the Judiciary and Status of Judges]," of July 7 , 2010, accessed June 20, 2018, http://zakon.rada.gov.ua/laws/show/2453-17.

"On the Judiciary and Status of Judges."

13 Kryminalniy protsesualnyi kodeks Ukrainy zi zminamy, vnesenymy zghidno iz Zakonom No. 529o-VI vid 18 veresnuia 2012 roku [Criminal Procedure Code of Ukraine as amended according to Law No. 529o-VI of September 18, 2012], accessed September 10, 2018, http:// zakon.rada.gov.ua/laws/show/1001-05. 
Article 400-13, referring to Article 384 of the 1960 Criminal Procedure Code of Ukraine, establishes the class of persons entitled to request a review of a Supreme Court of Ukraine decision, and Article 400-18 of this Code established the timeframe for filing said request. Articles 400-15-400-18 of the 196o Criminal Procedure Code of Ukraine specify the requirements for the request, the procedure for its validation and admission of cases to proceeding. ${ }^{15}$

In view of the above, until recently judicial practice separated mandates for review of court decisions. In particular, in a case where the ECHR established that Ukraine violated the Convention standards during the resolution of the court proceedings, the Supreme Specialized Court of Ukraine for Civil and Criminal Cases reviewed and decided cases as if such review resulted from the national court's violation of procedural laws. Meanwhile, the Supreme Court of Ukraine reviewed cases where the national court misapplied the standards of property law or of both property law and procedural law.

At that, the provisions of Article 40018 of the 196o Criminal Procedure Code of Ukraine, which provided grounds and procedure for resolving the issue of approval by the Supreme Specialized Court of Ukraine for Civil and Criminal Cases for a case to be transferred for review to the Supreme Court of Ukraine, were deemed to be constitutional based on Resolution of the Constitutional Court of Ukraine No. 17-rp/2011 of December 13, 2011. At the same time, judges and scholars criticized the mentioned provisions of the Law, because when the ECHR identifies violations of the Convention's norms, it usually does not differentiate between procedural and property law violations.

According to clauses 6, 7 of Section XII "Final and Transitional Provisions" of the Law of Ukraine "On the Judiciary and Status of Judges" of June 2, 2016, beginning the day the newly established Supreme Court starts operating, all cassation courts of Ukraine and the former Supreme Court of Ukraine shall cease to operate. ${ }^{16}$

\section{Conclusion 2}

Taking into account that currently the process of dissolving the Supreme Court of Ukraine (which has a constitutional status and is a legal entity of public law), as the highest judicial body is still underway, it no longer has the procedural mandate to consider the issues mentioned above. If a recognized international judicial institution identifies a violation of Ukraine's international commitments during the court proceedings, an application for review of the judicial decision due to exceptional circumstances shall be filed to the Supreme Court that commenced operation on December 15, 2017. However, the articles of the 2012 Criminal Procedure Code of Ukraine, which address transfer of these proceedings from the Supreme Court of Ukraine to the Supreme Court, and the norms concerning the above-mentioned ground for the Supreme Court to consider applications from convicted persons, are articulated incorrectly in view of how they

15 Criminal Procedure Code of Ukraine.

16 "On the Judiciary and Status of Judges." 
should be applied. This is why they are often interpreted and applied inconsistently in practice. To address this gap, the legislation needs to determine the duration of the transitional period and delineate two different procedures for the Supreme Court's review of applications of those convicted in criminal cases in which the ECHR Convention may have been violated. In the first instance, these complaints concerning criminal cases which were submitted to the ECHR and admitted for examination before the abovementioned Law of Ukraine No. 2147-VIII of October 3, 2017, became effective. The second instance applies to the complaints concerning criminal cases which were submitted to ECHR and admitted for examination after the above- referenced Law became effective and significantly changed the procedure for consideration in the Supreme Court.

\section{Another legislative challenge is the absence of an effective mechanism for obtaining records from a criminal proceeding, when it is impossible to retrieve cases from the courts in the temporarily occupied territories.}

Indeed, the state of Ukraine guarantees observance of human rights and freedoms and it has created (and should continue to improve) its own proper legal mechanisms to protect them. Ukraine's adherence to its commitments in relation to people convicted by the courts located in uncontrolled territories is of special urgency.

According to clauses 1, 14 of Part 1, Article 92 of the Constitution of Ukraine, human rights and freedoms, and guarantees to uphold them, as well as the judicial procedure, are governed exclusively by the laws of Ukraine. ${ }^{17}$

Every person has the right to a fair and public hearing of their case within a reasonable time by an independent and impartial tribunal established by law, which will resolve any dispute about his civil rights and obligations, or will determine if any criminal charge against him is justified (clause 1, Article 6 of the Convention, which is part of the national legislation)..$^{18}$

Every person judged as guilty of a criminal offence by the court has the right to have the guilty verdict or the sentence in question reviewed by a court of higher instance. Implementation of this right, including what constitutes a valid reason for review, is defined by law (Article 2, Protocol No. 7 to the Convention). ${ }^{19}$

The procedure for restoration of lost records from criminal proceedings was not addressed in the 196o Criminal Procedure Code of Ukraine. This fact did not prevent

Konstytutsia Ukrainy [Constitution of Ukraine] of June 28, 1996, accessed on September 10, 2018, http://zakon.rada.gov.ua/laws/show/254к/96-вр. 
scholars from expressing their own opinions about restoration of lost (destroyed, stolen) records from criminal cases. ${ }^{20}$ Yet, their suggestions on how legislators should procedurally regulate this issue were not taken into account in the procedural law under effect at the time. Their focus was not and, a priori, could not have been on situations where criminal cases cannot be retrieved because the court in question is located in a temporarily occupied territory of Ukraine. At that time, the courts functioned in the standard mode of the unitary state of Ukraine.

Currently, Section VII of the in-effect Criminal Procedure Code of Ukraine of 2012 "Restoring Lost Records of Criminal Proceedings" consists of eight Articles, and specifies:

1) conditions of restoring lost records of criminal proceedings;

2) persons who may file with court an application for restoration of lost records of criminal proceedings;

3) jurisdiction of the application for restoration of lost records of criminal proceedings;

4) consequences of failure to comply with requirements for the application's content, refusal to open proceedings, or declining to consider the application;

5) preparation of the application for hearing;

6) provisions related to trial and ruling of the court. ${ }^{21}$

When addressing this issue, the court questions witnesses and examines the preserved records, including documents or copies thereof, issued to individuals or to legal entities. Then, the court uses other data that can help fill in the gaps, ${ }^{22}$ including electronic documents, which considerably improves the capacity to restore the lost records. ${ }^{23}$

The problem described above has been addressed in a number of scholarly articles. ${ }^{24}$ Yet, the authors of those articles just tackle general problems of restoration

20 Viktoria Kuzminova, Pravovi ta naukovi osnovy vidnovlennia (rekonstruktsii) vtrachenykh kryminalnykh sprav [Legal and Scholarly Grounds for Restoration (Reconstruction) of Lost Criminal Cases] (Kharkiv: Yaroslav Mudryi National Legal Academy of Ukraine, 2002).

21 Criminal Procedure Code of Ukraine.

22 Valentyn V. Kovalenko, Larysa D. Udalova and Dmytro P. Pysmenny, Kryminalny protses [Criminal Proceeding] (Kyiv: Tsentr uchbovoi literatury, 2013). 497.

Volodymyr Tertyshnyk, Naukovo-praktychny komentar Kryminalnoho Protsesualnoho kodeksu Ukrainy [Annotated Criminal Procedure Code of Ukraine] (Kyiv: Pravova yednist, 2017) 709..

24 Andriy Romaniuk, "Problemni pytannia pravovoho rehuliuvannia vidnovlennia vtrachenykh materialiv kryminalnoho provadzhennia v Ukraini [Challenges of Legal Regulation of Restoration of Records of Criminal Proceedings in Ukraine]" Naukovi pratsi Natsionalnoho Universytetu “Odeska Yurydychna Akademiia” 11 (2012): 438-45; Andriy Malaniuk, "Zahalni umovy zdiysnennia provadzhennia z vidnovlennia vtrachenykh materialiv u kryminalnomu sudochynstvi Ukrainy [General Conditions for Proceedings on Restoration of Lost Records in Criminal Procedure of Ukraine]," Visnyk Lvivskoho Universytetu. Seria yurydychna 64 (2017): $235-44$ 
of lost records of criminal proceedings, without specifically addressing the problem that it is impossible to retrieve these records from courts located in territories not controlled by Ukraine. For our research, however, this problem is of key importance.

At the same time, lack of an effective legal mechanism for restoring records, when it is impossible to transfer the case from a court located in an occupied territory, in practice, renders securing a proper judicial protection as required by Clause 1, Article 6 of the Convention impossible. It is also problematic to contest court decisions in courts of appeals or cassation, as guaranteed by the Constitutional Law of Ukraine. Therefore, this issue calls for legislative regulation. ${ }^{25}$

This is how the Parliamentary Committee on Legal Policy and Justice defined the current situation, when it examined the draft Law of Ukraine for compliance with the Ukrainian Constitution at its session on February 28, 2018 (Protocol No. 67), "On Amendments to Criminal Procedure Code of Ukraine (on improvement of the procedure of restoration of criminal proceedings, or separate records thereof, lost on the stage of pre-trial investigation and trial)" (No. 6580, of June 12, 2017). That said, the Parliamentary Committee for Legislative Support of Law Enforcement Activities examined this draft and established that its goal is legislative codification of the mechanism for restoration of records of criminal proceedings retained in the courts in territories under temporary occupation, or in locations where anti-terrorist operations are conducted. This analysis includes application of proper legal procedure to each party. After analyzing the Draft, the Committee members approved the decision to recommend that Verkhovna Rada of Ukraine approve it in principle. ${ }^{26}$

The Chief Office for Research and Evaluation of the Administration of Verkhovna Rada of Ukraine believed after first reading, that the draft required some follow-up revision. In the development of this draft one of the main principles of legislative procedure - coherence between different norms of law — was violated, among other things. It was also pointed out that Verkhovna Rada of Ukraine is currently reviewing the draft of the Law of Ukraine "On Amendments to the Law of Ukraine "On Securing

25 Vysnovok Komitetu Verkhovnoi Rady Ukrainy z pytan pravovoi polityky ta pravosuddia shchodo proektu Zakonu pro vnesennia zmin do Kryminalnoho protsesualnoho kodeksu Ukrainy (shchodo vdoskonalennia poriadku vidnovlennia kryminalnoho provadzhennia abo yoho okremykh materialiv, vtrachenykh na stadiakh dosudovoho rozsliduvannia ta sudovoho rozghliadu) (Conclusion of the Committee of Verkhovna Rada of Ukraine on Legal Policy and Justice on the draft of the Law of Ukraine "On Amendments to Criminal Procedure Code of Ukraine (Concerning Improvement of the Procedure of Restoration of Criminal Proceedings, or Separate Records Thereof, Lost on the Stage of Pre-trial Investigation and Trial) No. 658 o of June 12, 2017), accessed June 20, 2018, http://w1.c1.rada.gov.ua/pls/zweb2/ webproc4_1?pf3511=62007.

26 Conclusion of the Committee of Verkhovna Rada of Ukraine on Legal Policy and Justice on the draft of the Law of Ukraine "On Amendments to Criminal Procedure Code of Ukraine (Concerning Improvement of the Procedure of Restoration of Criminal Proceedings, or Separate Records Thereof, Lost on the Stage of Pre-trial Investigation and Trial". 
Rights and Freedoms of Citizens and Legal Framework on the Territory of Ukraine under Temporary Occupation Concerning the Mechanism for Restoration of Lost Case Records" (No. 3343 of October 19, 2015), which is intended to address very similar issues. Because of this, it was recommended that both drafts - No. 6580 and No. 3343 be considered at the same time. ${ }^{27}$ Currently, both drafts have been included to the agenda (Decree of the Verkhovna Rada of Ukraine of March 20, 2018, No. 2351-VIII) and are awaiting consideration.

In addition, on February 27, 2017, the members of the Committee for Human Rights, Ethnic Minorities, and Inter-Ethnic Relations introduced a draft Decree of the Verkhovna Rada of Ukraine "On Dismissing Draft of the Law of Ukraine "On Amendments to the Law of Ukraine "On Securing Rights and Freedoms of Citizens and Legal Framework on the Territory of Ukraine under Temporary Occupation" concerning the mechanism of restoration of lost case records" (No. 3343/P). On March 14, 2017, the Committee proposal to dismiss it was filed.

At the same time, the draft of the Law of Ukraine "On Amendments to Criminal Procedure Code of Ukraine (Concerning Improvement of the Procedure of Restoration of Criminal Proceedings, or Separate Records Thereof, Lost on the Stage of Pre-trial Investigation and Trial)" (No. 6580 of June 12, 2017) in its current published form does not resolve the existing problem of creating a legal mechanism for the restoration of court records in cases where retrieval is impossible due to the court's location in a temporarily occupied territory, for a number of reasons.

Article 531-1 of the 2012 Criminal Procedure Code of Ukraine (as worded in the draft) stipulates that the proceedings can be restored if, before they were lost, any of the following took place:

1) a conclusion to indict (request to apply medical care, etc.) was taken to the court, yet a preparatory court session never took place;

2) the court trial started, but a court decision based the trial results was never approved;

3) the court approved a decision to stop court proceedings based on Article 335 of the Criminal Procedure Code;

4) the court pronounced its sentence, yet it never took legal effect, for different reasons;

27 Vysnovok Holovnoho naukovo-ekspertnoho upravlinnia Aparatu Verkhovnoi Rady Ukrainy na proekt Zakonu Ukrainy "Pro vnesennia zmin do kryminalnoho protsesualnoho kodeksu Ukrainy (shchodo vdoskonalennia poriadku vidnovlennia kryminalnoho provadzhennia abo yoho okremykh materialiv, vtrachenykh na stadiakh dosudovoho rozsliduvannia ta sudovoho rozghliadu)" (Conclusion of the Chief Office for Research and Evaluation of the Administration of Verkhovna Rada of Ukraine on the draft of the Law of Ukraine "On Amendments to Criminal Procedure Code of Ukraine (Concerning Improvement of the Procedure of Restoration of Criminal Proceedings, or Separate Records Thereof, Lost on the Stage of Pre-trial Investigation and Trial)" (No. 6580 of June 6, 2017), accessed June 20, 2018, http://w1.c1.rada.gov.ua/pls/ zweb2/webproc4_1?pf3511=62007. 
5) the pronounced sentence took legal effect, but was not filed for enforcement;

6) the sentence never took legal effect for other reasons. ${ }^{28}$

\section{Conclusion 3}

Adoption of the Law of Ukraine in the proposed wording does not provide for restoration of records of criminal proceedings that were lost after approval of a court sentence. In particular, this relates to restoring records of proceedings, where retrieval is impossible (due to practical reasons, related to courthouses, prosecutor's offices, and police stations being captured by unlawful militant groups, who do not respond to any requests for records). Therefore, there is an urgent need to codify and clearly establish the procedure for restoring such records, which should be different from the general one. Resolving this issue on the legislative level will allow achievement of the goals of criminal proceedings defined in Part 1, Article 2, of the 2012 Criminal Procedure Code of Ukraine - in particular, those related to protecting rights, freedoms, and legitimate interests of its parties, with application of proper legal procedure.

\section{Final Conclusions}

1. According to the existing legislative requirements, in Ukraine, an application for review of a court decision due to such exceptional circumstance as ECHR identifying violations of the Convention (and correspondingly, a violation by Ukraine of its international commitments) in resolution of a case by the court, is to be filed to the Supreme Court, which became operational on December 15, 2017.

When reviewing such application, the Supreme Court should be guided in its decision by the available materials, which include whatever materials the ECHR decision was based upon, the text of the said decision, and the criminal case records.

At that, the effective Criminal Procedure Code of Ukraine does not define a binding set of rules for the Supreme Court to request the records of a criminal case, in which ECHR identified violations of the Convention in the course of pretrial investigation or legal proceedings. The courts in temporarily occupied territories of Ukraine do not comply with the Supreme Court's requests for such case records. Under these conditions, the only way to resolve this situation is to develop and enforce a special procedure of restoration of criminal case records. Unfortunately, such a procedure is not currently provided for in the Criminal Procedure Code of Ukraine.

28 Proekt Zakonu Ukrainy "Pro vnesennia zmin do kryminalno-protsesualnoho kodeksu Ukrainy (shchodo vdoskonalennia poriadku vidnovlennia kryminalnoho provadzhennia abo yoho okremyh materialiv, vtrachenykh na stadiakh dosudovoho rozsliduvannia ta sudovoho rozghliadu)" (Draft of the Law of Ukraine "On Amendments to Criminal Procedure Code of Ukraine [Concerning Improvement of the Procedure of Restoration of Criminal Proceedings, or Separate Records Thereof, Lost on the Stage of Pre-trial Investigation and Trial]" No. 6580 of June 12, 2017), accessed June 20, 2018, http://w1.c1.rada.gov.ua/pls/zweb2/ webproc4_1?pf3511=62007. 
2. Applications for review of a court decision on this ground, which were filed to the old Supreme Court of Ukraine, are subject to transfer to the new Supreme Court, and the subsequent proceedings are also to be conducted based on the rules for review of court decisions due to extraordinary circumstances in accordance with Chapter 34 of the Criminal Procedure Code of Ukraine.

Thus, the legislation does not set a transitional period, and does not delineate two different procedures for the Supreme Court's review of applications from individuals convicted in criminal cases, concerning which ECHR identified violations of the Convention. These are the criminal cases with complaints which were submitted to ECHR and admitted for examination before the Law of Ukraine No. 2147-VIII of October 3, 2017, became effective, and complaints regarding criminal cases which were submitted to ECHR and admitted for examination after the mentioned Law went in to effect and significantly changed the procedure for consideration of such cases in the Supreme Court.

3. The impossibility of retrieving records and criminal cases files from courts located in temporarily occupied territories is an obstacle when the Supreme Court considers applications for review of court decisions due to extraordinary circumstances. Without these records, in some cases (in particular, when the Supreme Court is overturning the decisions of lower courts), it is impossible to conduct the proceedings. The general procedure for restoration of lost records currently established by the Criminal Procedure Code of Ukraine does not address this problem. Therefore, there is a pressing need to codify and clearly establish the procedure for restoration of such records. Resolution of this issue on the legislative level is also important because the issues related to Ukraine's adherence to its international commitments is certainly something the Supreme Court will have to address multiple times as it considers applications from individuals in the cases that were tried in courts in territories now under temporary occupation.

\section{Bibliography}

Bernatska, Natalia. "Miniust znayshov mehanizm vykonannia rishennia ESPL u spravi "Burmych ta inshi proty Ukrainy" [Ministry of Justice Found a Mechanism to Implement ECHR Judgment in Case Burmych and Others v. Ukraine]." Accessed September 10, 2018. https://minjust.gov.ua/news/ministry/nataliya-bernatskaminyust-znayshov-mehanizm-vikonannya-rishennya-espl-u-spravi-burmich-tainshi-proti-ukraini.

Convention for the Protection of Human Rights and Fundamental Freedoms of November 4, 1950. Accessed September 10, 2018. http://zakon.rada.gov.ua/laws/ show/995_004.

Konstytutsiia Ukrainy [Constitution of Ukraine of June 28, 1996]. Accessed September 10, 2018. http://zakon.rada.gov.ua/laws/show/254к/96-вp.

Kovalenko, Valentyn V., and Larysa D. Udalova, and Dmytro P. Pysmenny. Kryminalny protses [Criminal Proceeding]. Kyiv: Tsentr uchbovoi literatury, 2013. 
Kryminalnyi protsesualnyi kodeks Ukrainy (zi zminamy, vnesenymy zghidno iz Zakonom No. 529o-VI vid 18 veresnia 2012 roku) [Criminal Procedure Code of Ukraine (As Amended According to Law No. 5290-VI of September 18, 2012)]. Accessed September 10, 2018. http://zakon.rada.gov.ua/laws/show/1001-05.

Kryminalnyi protsesualnyi kodeks Ukrainy [Criminal Procedure Code of Ukraine] of April 13, 2012. Accessed June 20, 2018. http://zakon.rada.gov.ua/laws/show/465117/page16.

Kuzminova,Viktoria. Pravovi ta naukovi osnovy vidnovlennia (rekonstruktsii) vtrachenykh kryminalnykh sprav [Legal and Academic Basis of Restoration (Reconstruction) of Lost Criminal Cases]. Kharkiv: Natsionalna yurydychna akademiia Ukrainy im. Yaroslava Mudroho, 2002.

Malaniuk, Andriy H. "Zahalni umovy zdiysnennia provadzhennia z vidnovlennia vtrachenykh materialiv u kryminalnomu sudochynstvi Ukrainy [General Conditions for Proceedings on Restoration of Lost Records in Criminal Procedure of Ukraine]." Visnyk Lvivskoho Universytetu. Seria Yurydychna 64 (2017): 235-44.

Ministry of Justice of Ukraine. "ECHR Rulings Made Regarding Ukraine" (old version). Accessed September 10, 2018. http://old.minjust.gov.ua/9329.

Pavlov and Others v. Ukraine. (ECHR, November 5, 2015). Accessed September 14, 2018. https://hudoc.echr.coe.int/ eng\#\{\%22appno\%22:[\%228237/06\%22],\%22itemid\%22:[\%22001-158535\%22]\}.

Proekt Zakonu Ukrainy "Pro vnesennia zmin do kryminalnoho protsesualnoho kodeksu Ukrainy (shchodo vdoskonalennia poriadku vidnovlennia kryminalnoho provadzhennia abo yoho okremyh materialiv, vtrachenykh na stadii dosudovoho rozsliduvannia ta sudovoho rozghliadu)" [Draft of the Law of Ukraine "On Amendments to Criminal Procedure Code of Ukraine (Concerning Improvement of the Procedure of Restoration of Criminal Proceedings, or Separate Records Thereof, Lost on the Stage of Pre-trial Investigation and Trial)]" No. 6580 of June 12, 2017. Accessed June 20, 2018. http://w1.c1.rada.gov.ua/pls/zweb2/ webproc4_1?pf3511=62007.

Protocol No. 7 of November 22, 1984, to Convention for the Protection of Human Rights and Fundamental Freedoms. Accessed September 10, 2018, http://zakon.rada.gov. ua/laws/show/994_804.

Romaniuk, Andriy B. "Problemni pytannia pravovoho rehuliuvannia vidnovlennia vtrachenykh materialiv kryminalnoho provadzhennia v Ukraini [Challenges of Legal Regulation of Restoration of Records of Criminal Proceedings in Ukraine]." Naukovi pratsi Natsionalnoho Universytetu "Odeska Yurydychna Akademiia" 11 (2012): 438-45.

Tertyshnyk, Volodymyr. M. Naukovo-praktychnyi komentar kryminalnoho protsesualnoho kodeksu Ukrainy [Annotated Criminal Procedure Code of Ukraine]. Kyiv: Pravova yednist, 2017.

Vronska, Anna. "Shcho neobkhidno znaty pro vnutrishniu orhanizatsiu, format rishen ta systematyzatsiu sudovoi praktyky Verkhovnoho Sudu? [What You Should Know 
About Internal Structure, Format of Decisions and Systematization of Case Law of the Supreme Court?]." Accessed September 10, 2018. http://jurliga.ligazakon. ua/news/2018/2/23/168669. htm.

Vysnovok Holovnoho naukovo-ekspertnoho upravlinnia Aparatu Verkhovnoii Rady Ukrainy na proekt Zakonu Ukrainy "Pro vnesennia zmin do kryminalnoho protsesualnoho kodeksu Ukrainy (shchodo vdoskonalennia poriadku vidnovlennia kryminalnoho provadzhennia abo yoho okremyh materialiv, vtrachenykh na stadiakh dosudovoho rozsliduvannia ta sudovoho rozhliadu)" [Conclusion of the Chief Office for Research and Evaluation of the Administration of Verkhovna Rada of Ukraine on the draft of the Law of Ukraine "On Amendments to Criminal Procedure Code of Ukraine (Concerning Improvement of the Procedure of Restoration of Criminal Proceedings, or Separate Records Thereof, Lost on the Stage of Pre-trial Investigation and Trial)]" No. 6580 of June 12, 2017. Accessed June 20, 2018. http://w1.c1.rada.gov.ua/pls/zweb2/webproc4_1?pf3511=62007.

Vysnovok Komitetu Verkhovnoi Rady Ukraiiny z pytan pravovoi polityky ta pravosuddia shchodo proektu Zakonu pro vnesennia zmin do kryminalnoho protsesualnoho kodeksu Ukrainy (shchodo vdoskonalennia poriadku vidnovlennia kryminalnoho provadzhennia abo yoho okremyh materialiv, vtrachenykh na stadiakh dosudovoho rozsliduvannia ta sudovoho rozghliadu) [Conclusion of the Committee of Verkhovna Rada of Ukraine on Legal Policy and Justice on the draft of the Law of Ukraine "On Amendments to Criminal Procedure Code of Ukraine (Concerning Improvement of the Procedure of Restoration of Criminal Proceedings, or Separate Records Thereof, Lost on the Stage of Pre-trial Investigation and Trial] No. 658 o of June 12, 2017. Accessed June 20, 2018. http://w1.c1.rada.gov.ua/pls/ zweb2/webproc4_1?pf3511=62007.

Zakon Ukrainy "Pro sudoustrii i status suddiv" [Law of Ukraine "On the Judiciary and Status of Judges,"] of July 7, 2010. Accessed on June 20, 2018. http://zakon.rada. gov.ua/laws/show/2453-17.

Zakon Ukrainy "Pro vnesennia zmin do Hospodarkoho protsesualnoho kodeksu Ukrainy, Tsyvilnoho protsesualnoho kodeksu Ukrainy, Kodeksu administratyvnoho sudochynstva Ukrainy ta inshykh zakonodavchykh aktiv" [Law of Ukraine "On Amendments to Economic Procedure Code of Ukraine, Civil Procedure Code of Ukraine, Administrative Procedure Code of Ukraine, and Other Legislative Acts"] of October 3, 2017, No. 2147-VIII. Accessed June 10, 2018, http://zakon.rada.gov.ua/ laws/show/2147-19.

Iryna Basysta is Doctor of Legal Sciences, Professor. Worked in investigation units, and later - as an educator. She received her Doctor's degree in Law in 2014 at the Classical Private University (Zaporizhzhia), and her academic rank of professor - in 2016 at the National Academy of Internal Affairs (Kyiv). Since 2017, she has been working at Lviv State University of Internal Affairs, Lviv, Ukraine. She is currently a professor 
of the Criminal Procedure and a member of the Academic Advisory Council of the Supreme Court.

Volodymyr Galagan is Doctor of Legal Sciences, Professor. He worked in investigation units, and later - as an educator. He received his Doctor's degree in Law in 2004 at the National Academy of Internal Affairs of Ukraine (Kyiv), and his academic rank of professor - in 2006, at the same educational institution. Since 2010, he has been working at the National University of Kyiv-Mohyla Academy, Kyiv, Ukraine. He is currently chairing the Department of Criminal Law and Criminal Procedural Law. 